\title{
Workers' compensation experience-rating rules and the danger to workers' safety in the temporary work agency sector
}

Ellen MacEachen PhD, ${ }^{a, b}$ Katherine Lippel LLL LLM FRSC, ${ }^{c}$ Ron Saunders PhD, ${ }^{a, b}$ Agnieszka Kosny PhD, ${ }^{a}$ Liz Mansfield PhD, ${ }^{a}$ Christine Carrasco BSc (Hons) MPH and

Diana Pugliese BA (Hons) ${ }^{\mathrm{a}}$

a Institute for Work \& Health, Canada

${ }^{b}$ University of Toronto, Canada

' University of Ottawa, Canada

\section{Abstract}

By putting a price on workplace health and linking this to costs incurred in individual businesses, experience-rating rules encourage employer 'gaming' - cost-reduction attempts that do not necessarily increase workplace safety. We argue that experience-rating rules, together with the rise of non-standard employment arrangements, have fostered the growth of the temporary work agency sector to which employers can outsource workplace injury risk.

This study explored how temporary work agencies in Ontario, Canada carry out workplace injury prevention and return to work. We aimed to understand why these agencies would shoulder experience-rating costs when they cannot control the work environment. Focus groups and in-depth interviews were held with 64 participants between 2009 and 2011. Participants included low-wage agency workers, temporary work agencies, client employers and key informants. Legal and documentary data were also analysed.

Our findings show how experience-rating rules create a market for outsourcing risky jobs to temporary work agencies, which cannot properly manage injury prevention and return to work. We detail how agencies are positioned to absorb experience-rating costs for their clients and avoid financial risk through cost transfer, premium rate groups, legal positioning, influencing accident reporting practices, and shutting down and re-opening the business.

Our findings also show how experience-rating arrangements can distort the responsibility these agencies have for work and health. In Ontario, these facilitate employer 'gaming', largely within the rules. We propose that workplace health would be less of a tradeable commodity, and workers' safety and return to work a more significant priority for employers, if experience rating were applied to the client employer who controls the conditions of work.

\section{Key words}

Experience rating, return to work, risky work, temporary work agencies, vulnerable workers, workers' compensation

\section{Introduction}

Experience rating is usually discussed in relation to the distribution of workplace accident 
costs among employers and incentive effects on the management of workplace-level occupational safety and health $(\mathrm{OSH})$ prevention and return to work..$^{1-4}$ The encouragement of $\mathrm{OSH}$ in workplaces by such indirect financial mechanisms has face appeal because it appears to supplement state efforts to regulate and enforce OSH standards. However, in drawing a link between health and safety and financial incentives, experience rating puts a price on workplace health, making it a market commodity. In turn, this encourages 'gaming' among employers - attempts to reduce their workers' compensation premium costs that do not necessarily increase workplace safety. ${ }^{2}$ Others have reported how employers appear to avoid experience-rating costs by skirting the rules, for instance by under-reporting the number of staff in a higher rate group ${ }^{2}$ and suppressing injury reporting. However, strategies such as appealing claims and rushing workers back to work $^{5-7}$ can lower experience-rating costs without making health and safety improvements, all within the rules.

In this paper, we argue that experience-rating arrangements have encouraged the growth of the temporary work agency (TWA) sector. By linking workers' compensation premiums to related costs incurred by individual businesses, experience rating provides an incentive for employers to outsource risky work. Further, the injury prevention and management incentives embedded in experience rating, as played out in the triangular employment relationship between workers, employers and TWAs, facilitates experience-rating gaming. Of course, experience-rating is not necessarily a single or determining factor in the success of TWAs. Other jurisdictions, such as the United Kingdom, Sweden and Spain, have flourishing TWA sectors but no experience rating in relation to workplace safety. ${ }^{8}$ Rather, we detail under-discussed aspects of how experience-rating encourages the commoditisation of work injury and how experience-rating arrangements can create value for the TWA sector.

The TWA sector is a flourishing ${ }^{9-10}$ and increasingly established part of new flexible labour markets, where the labour forces of organisations can be quickly increased or decreased in line with demand for labour. ${ }^{11-13}$ Agencies offer many services to employers who wish to avoid human resources-related tasks and expenses, ${ }^{14}$ among them the absorption of health and safety costs. ${ }^{15-16}$ In theory, the shifting of workplace health and safety costs from one employer (the client employer) to another (the TWA) should have negligible effects. However, as we will describe, this scenario implies less OSH protection for TWA workers than for regular workers.

\section{Literature review}

\section{The establishment and role of TWAs}

Temporary work is strongly present in advanced economies. In the USA, temporary help services grew from 1.1 million workers in 1990 to 2.3 million workers in 2008, representing 1.7 per cent of total US employment. ${ }^{10}$ Over the 1990 s, temporary agency work doubled in most European Union countries, and increased five-fold in Scandinavia, Spain, Italy and Austria. ${ }^{17}$

There are significant discrepancies in pay between temporary workers and full-time staff in the same workplace. A Canadian study ${ }^{18}$ found that while seasonal workers earned 28 per cent less than their permanent counterparts, and casual workers 24 per cent less, those using employment agencies had the largest discrepancy, at 40 per cent less. In general, temporary agency workers face extremely precarious work conditions with no job security. ${ }^{19}$

Temporary work dates back to the beginnings of the Industrial Revolution. However, its current manifestation is novel. While temporary workers were once used primarily to fill in for sick employees or permanent employees on vacation, since the early 1990 s there has been a 
new style of labour resourcing in which client companies contract with TWAs to supply part of their workforce as a medium- or long-term strategic alternative to direct employment. ${ }^{20}$ In some cases, permanent jobs are being converted into temporary positions. ${ }^{14,21}$ Temporary workers are now frequently employed on an ongoing basis.

The complex, three-way employment relationship

Temporary work involves a complex triangular arrangement in which the agency hires a worker for the purpose of placing them at the disposal of a third party. The TWA is generally considered to be the 'employer' of a person it sends to work for a client business. ${ }^{16,22-23}$ However, the legal and practical responsibilities of each party are not always clear ${ }^{16,24}$ and agency workers can be uncertain of the identity of their employer. ${ }^{25}$

Temporary work situations expose workers to fundamentally different power dynamics than standard, bilateral employment relations. ${ }^{26}$ The separation of the 'legal employer' from the 'supervising employer' subjects workers to two figures of authority. Workers are subject to the demands of the client employers but do not have the same hope of security and advancement as 'real' employees. At the same time, the agency employer is ill-suited to evaluate workers' performance. Although the agency, not the client business, is responsible for ensuring workers' employment standards rights are met, they have no direct knowledge of the work in which workers are engaged. ${ }^{27}$

\section{The high accident rate among TWAs}

Temporary workers, including agency workers, are at greater risk of occupational accidents and diseases than permanent workers. ${ }^{19,28-29}$ In the Netherlands and Germany, TWA workers accounted for as much as 13 per cent of occupational accidents, although they fill only 3 per cent of the jobs. ${ }^{30}$ In Finland, workplace accident frequency for temporary agency workers is on the increase, despite a general downward trend in main industries. ${ }^{31}$ In the USA, compared to workers in standard employment arrangements, temporary agency workers have higher workers' compensation claim incidence rates ${ }^{32-33}$ and longer claim durations, ${ }^{33}$ and in the construction and manufacturing sectors, they are twice as likely to incur an injury. ${ }^{32}$

\section{Method}

This paper is based on a larger study conducted in 2009-2012 into how injury prevention and return to work are carried out in TWAs in Ontario, Canada, particularly in relation to temporary agency workers in low-skill jobs. ${ }^{24}$ A qualitative research design allowed for a broad enquiry that accessed the work life and occupational health experiences of multiple players involved in the sector.

\section{Sample and recruitment}

Focus groups and in-depth interviews were conducted with 64 agency workers, agencies, client employers and key informants (see Table 1). We sought participants across four locations in Ontario: a large city with mixed industries, a suburban area, a mid-sized city with a declining manufacturing centre, and a mid-sized city with a booming high-tech sector.

The worker sample was purposely focused on workers engaged in relatively low-skill jobs, such as general labour, warehouse and service work. The rationale was that these workers are more vulnerable than highly skilled TWA workers, such as nurses or IT professionals. Workers were recruited on the basis of having worked for TWAs in the previous 12 months in a range of unskilled and semi-skilled jobs, with and without related injury experience, and for a variety of agencies and locations. They were solicited via classified ads on the internet inviting 
TWA workers to share 'what it is like to be a temporary worker' and to discuss 'how temporary work agencies handle workplace health and safety issues', and also via the 'snowball' method (whereby one participant or contact suggests another to be included in the study). Eleven workers reported having been injured while working for an agency, and seven had a related workers' compensation claim.

TWAs were purposively selected so that there was a wide range in terms of organisation size and location. A further consideration was that they offered unskilled and/or semi-skilled work. Participants were recruited via cold calling. Included in the study were six multinational, two mid-sized (three or more branches) and nine small (one or two offices) agencies. We recruited client employers via cold calling, chosen for the kinds of work site described by the workers and for having hired agency labour in the previous 12 months. Key informants were identified via the 'snowball' method and for their direct knowledge of the TWA sector.

Data gathering and analysis

Interviews and focus groups were conducted with all participant categories and led by study team members. Focus groups included two to six participants and lasted approximately two hours; one-to-one interviews took approximately one hour.

\begin{tabular}{|c|c|c|c|c|c|}
\hline \multirow{6}{*}{$\begin{array}{r}\text { Table } 1 \\
\text { Research } \\
\text { participants }\end{array}$} & $\begin{array}{l}\text { Participant } \\
\text { category }\end{array}$ & Industry/Employment focus & $\begin{array}{l}\text { No. of focus } \\
\text { groups }\end{array}$ & $\begin{array}{l}\text { No. of } \\
\text { interviews }\end{array}$ & $\begin{array}{l}\text { Total no. of } \\
\text { participants }\end{array}$ \\
\hline & Workers & $\begin{array}{l}\text { Broad job range, mostly low } \\
\text { skill and some medium skill, } \\
\text { including office, warehouse and } \\
\text { truck driver jobs }\end{array}$ & 4 & 3 & 19 \\
\hline & $\begin{array}{l}\text { Client } \\
\text { employers }\end{array}$ & $\begin{array}{l}\text { Industries: transportation, } \\
\text { beverage manufacturing, } \\
\text { property management, } \\
\text { laboratory, charity, restaurant, } \\
\text { waste management, warehouse }\end{array}$ & 2 & 3 & $\begin{array}{l}12 \\
(11 \text { workplaces) }\end{array}$ \\
\hline & $\begin{array}{l}\text { Temporary } \\
\text { work agencies }\end{array}$ & $\begin{array}{l}\text { Jobs: manufacturing, general } \\
\text { labour, forklift operators, } \\
\text { special events, warehouse/ } \\
\text { logistics, clerical }\end{array}$ & 4 & 14 & $\begin{array}{l}22 \\
(17 \text { agencies })\end{array}$ \\
\hline & Key informants & $\begin{array}{l}\text { Workers' compensation and } \\
\text { occupational safety and health } \\
\text { regulators, workers' } \\
\text { compensation policy and legal } \\
\text { advisers, safety inspector, } \\
\text { industry representatives, worker } \\
\text { advocate }\end{array}$ & 3 & 3 & 11 \\
\hline & \multicolumn{2}{|c|}{ Total participants } & 13 & 22 & 64 \\
\hline
\end{tabular}


Questions focused on:

- participants' experience of work with or for a TWA

- the pros and cons of working with a TWA/temporary workers/client employers

- communication and contractual arrangements

- labour challenges

- work and health issues

- injury prevention and return-to-work management.

Interviews were audio recorded and transcribed verbatim by an experienced transcriber.

Documentary data were also collected and analysed, including legal analysis of the Ontario Workplace Safety and Insurance Act (WSIA), the Occupational Health and Safety Act (OHSA), Workplace Safety and Insurance Board (WSIB) policy, and case law on all issues pertaining to workers' compensation and OSH as applied to TWAs in Ontario. ${ }^{24}$ These provided analytic context for the interpretation of participant accounts and helped frame data gathering.

All interview data were analysed using elements of situational analysis ${ }^{34}$ and following systematic data coding procedures. ${ }^{35}$ That is, we pursued an empirical approach, with analysis beginning with the first collected data, and sampling and subsequent data gathering guided by theoretical concerns emerging in the provisional analysis. We were sensitive to the positioning of participant discourse in the context of social, economic and legal conditions. All data analyses were conducted by several team members and discussed at regular team meetings.

A nine-member, multi-stakeholder advisory committee provided feedback and guidance at several key intervals of the study. It included labour representatives, legal experts, workers' compensation personnel, the labour ministry, employer advisers and worker advisers. The study design and procedures were approved by the University of Toronto's Research Ethics Board. All participants were assured of anonymity and confidentiality - participants' names in this paper are pseudonyms.

\section{Findings}

In Ontario, experience rating was established 'to encourage employers to reduce injuries and occupational diseases and to encourage workers' return to work'. ${ }^{36}$ Ontario's workers' compensation board clearly states that the TWA is the employer of agency workers: ${ }^{22}$

In the supply of labour industry, the agency supplying and paying the worker, not the employer to whom the worker is supplied, is responsible for covering the agency's workers under the Workplace Safety and Insurance Act.

In Ontario, TWAs are liable for workers' compensation premiums, which are experience-rated and subject to surcharges or rebates.

The experience-rating model presumes that applying financial incentives can encourage employers to reduce occupational injuries and diseases. However, in the case of the TWA sector, the agency does not control the work sites to which it sends workers, nor can it ensure that the jobs workers do correspond to what they were assigned to perform. The experiencerating model is also presumed to encourage return to work, yet the TWA is never the direct provider of work. 
The question arises as to why TWAs would shoulder experience-rating costs when they cannot control the work site. In this section, we show how experience rating creates a market to outsource risky jobs to TWAs. We argue that agencies cannot effectively manage workers' health and safety, leaving them particularly exposed to hazards and injury. Then, we show the various ways that TWAs are positioned to absorb experience-rating costs of work injuries through gaming strategies, including legal positioning, the management of injury reporting and, in extreme conditions, by shutting down and re-opening their businesses.

\section{Experience rating, risk and worker vulnerability}

In Ontario, under the WSIA, only one of the two employers in the three-way employment relationship is provided with a financial incentive for injury prevention and return to work: the TWA. This structure had two key effects. First, it creates a market to outsource dangerous work to TWAs. Second, it leaves workers vulnerable because agencies cannot effectively manage their health and safety.

In this study, both TWAs and client employers spoke openly about the shifting of dangerous work to agencies, and workers' compensation premium rates encouraged this shifting of risk. Agency workers were hired for client employer convenience, including the avoidance of workers' compensation costs and externalisation of risky work:

To be frank, clients hire us to have temps do the jobs they don't want to do. (Maurice, risk management specialist, multinational TWA)

As described by a client employer, agency workers were hired to relieve core workers of heavy work:

I'll hire a couple of guys for a half a day for unloading the container loaded with goods... And it's just heavy duty work that I would rather not have my guys doing. (Stephen, site manager, client employer)

At times, the client employer practice of risk avoidance by hiring TWA workers meant that TWA workers faced fatal job conditions and were killed:

There was a steel container of plywood sheeting came from [abroad]... and then a company in [Ontario] bought this load of lumber... and then they open it up... and they find that the material was stored unsafely inside the container... So, instead of sending their workers, they got a hold of this temporary agency. And they sent two... workers from the temporary agency. And then when the doors were open, when they were handling the material, the load came apart and killed the guy. (Joseph, OSH inspector)

Because client employers bore no workers' compensation costs for the agency workers under their supervision, they had little direct incentive to reduce risks to them, other than liability under the OHSA, ${ }^{37}$ which, while applicable, is less systematically enforced than experience rating. Indeed, it appeared that client employers could be unaware of injuries among TWA workers, knowing only that one worker has replaced another:

We heard constantly about [agency] guys not coming back... We'd ask, 'What happened to so and so?'... 'Oh, he's out, man, he hurt his back.' (Darren, site manager, client employer)

I was working... the dye made my hands swell... I went to a doctor... It took me a while to 
get better... I didn't go back to work there... I got a job somewhere else doing security. (Malek, temporary worker)

TWA staff saw the irony of some client employers receiving awards for safety performance when in fact they had merely outsourced the risky work to the agency:

We were providing industrial labour... to a client. The client was receiving an award [workers' compensation] for best health and safety practices. That day I had two people... rolled out the back door in the ambulance. The client kept his health and safety record up high because he outsourced to staffing companies all the risky jobs, all the heaviest lifting, all the jobs that required any type of dangerous work went to a staffing agency. So, his record looked... perfect... The WSIB thought he was great. (Vaughn, owner, mid-sized TWA)

Although TWAs were contracted by client employers to carry out risky work, they were poorly positioned to protect their workers. The agencies reviewed basic health and safety with their workers, such as standard hazardous materials information, and various paper and computer tests relative to their job placement. As well, many agencies described conducting pre-placement work site inspections. In these ways, some TWAs did what they could to ensure that workers were prepared for the work and that the site was safe at the time of placement.

However, attempts by TWAs to manage workplace safety had three critical weaknesses that left workers exposed. First, newness to the work site and site-specific hazards posed dangers to the worker, despite generic OSH training. Workers on a new site do not know their way around it and are unfamiliar with the workflow:

If it's your first time in a warehouse a lot of people don't even realise what's going on and they are just stumbling around and falling over and knocking things down... And it's just one of those things. (Sean, temporary worker)

Second, the work conditions at the time of the placement can be quite different to the actual day-to-day conditions. For instance, although safety guards are present, they might not be used:

We had... one customer who... has a habit of un-guarding their machinery as soon as our backs are turned... The only three incidents of injury that we have had in the past two years have all been in the same place, and all have been because they take the bottom guards off this machine. It moves a lot quicker. (Doug, owner, small TWA)

Third, TWA staff lack the occupational health appraisal skills of formally trained safety inspectors. This was apparent to an inspector who dealt with a fatality after an agency had assessed a client work site as safe for worker placement:

The other thing with the temp agency... they've started now, is they do an assessment of the company. So... somebody is supposed to go out and they do... a walk-around tour... [But] They don't know what they're looking at, even though they go and do a survey. Like the one with the guy that was killed and... they did a [site inspection] survey and part of that survey was [if it was] machine guarded and... nowhere [were they] even close to meeting the requirements. (Joseph, OSH inspector) 
Despite agency efforts to screen work sites and prepare workers for placements, they are necessarily less able than regular employers to protect workers from the risk of accidents. At the same time, agencies attract risky work.

\section{Managing workers' compensation costs for the client employer}

A worker who requires considerable medical treatment and recovery time will pose a significant 'lost time' cost to an employer, creating a large experience-rating surcharge. TWAs are positioned to manage workers' compensation costs for the client employer by absorbing accident costs and liability, and by paying low premiums because of their classification in relatively favourable rate groups.

Under the WSIA, when an accident or disease is caused by the negligence of another employer, all or part of the claim costs can be charged to that employer's cost record. However, we observed only the smaller agencies engaging in this 'transfer of cost' to the client employer. This occurred only when the firm's financial viability was at stake, and posed a complex and costly process:

We've run into cases where... somebody is brought in to move boxes around in the warehouse. And some manager comes along and says, 'Hey, we need some guy to come over and help with this machine over here and do some of this stuff.'... This kid was only... [young] and he got his whole [limb] crushed in this machine... The liability was put towards [us] and... [we] had to fight that and eventually... overturned it... But it took... substantial resources, in terms of legal and management expertise, to make that happen... And... we lost them as a client, which... we anticipated. (Jason, recruiter, mid-sized TWA)

We found that engaging in 'transfer of cost' was a business decision for TWAs rather than an issue of legal responsibility. The key reason why most TWAs in this study did not transfer cost, even when possible, appeared to be the possibility of net financial loss. As Jessica and Jeremy, recruiters in a mid-sized TWA explained, a breach of the client relationship could mean significant unpaid bills:

Interviewer: Have you ever tried to transfer the cost... to the client employer?

TWA: No./No... /Because it's good business. What's the first advice to you as my client 'Oh, and we're going to transfer the cost to you'? You know what they're going to say?/They will go to another agency./'See the door, out.'... 'Good-bye.' And you've got $\mathrm{C} \$ 25,000$ in bills, invoices, etcetera. They're not going to get paid.

Agencies took a broad view on workplace accidents, considering them in relation to 'tomorrow's business relations':

[Transfer of cost] will undermine if not destroy... our customer relationship and so there is no economic incentive. You have to look at the economic model and balance it with your moral model. You have to say, 'Is this customer going to fix their workplace? So, therefore I feel... it's morally acceptable for me to continue to do business with them tomorrow because they're going to fix the workplace.' And then if you try to transfer the claims cost of yesterday's claim, you will undermine your relationship of tomorrow's business relations. (Simon, TWA industry expert)

It appeared that employers were aware that agencies had a transfer-of-cost option and could activate their own influence to prompt cost avoidance: 
We have way too many casualties of people in this industry... trucks rolling over people's legs... Drivers not caring about the people they're working with and, unfortunately, in a lot of cases it's the temp agency worker that it happens [to]... We're aware they [TWA] could probably try to transfer cost to us... It's as simple as us picking up the phone and saying, 'Okay, we're going to get another agency'... It's probably not in their best interest to try that. (Drake and Gordon, site managers, client employer)

A further deterrent to transferring costs to client employers is the Workplace Safety and Insurance Appeals Tribunal, which, in the past, has refused to transfer all costs to the client employer, despite their contributing negligence, finding the TWA to have failed to clarify the workers' duties. ${ }^{40}$

An important aspect of the client employer-TWA relationship is workers' compensation premium rates. These encourage outsourcing of risky work to the firm with the lower workers' compensation premium rate. Although employer premium rates are established to reflect the risk of work in different sectors, injury resulting from work outsourced to a TWA is potentially assessed at a relatively low risk rate. For instance, the WSIB's 2011 employer classification rate $^{38}$ for TWAs - at $C \$ 4.83$ per $C \$ 100$ of payroll - was $C \$ 2$ lower than that of employers in the 'wooden boxes and pallets' classification, who had a premium rate of C\$6.83. When TWA workers do 'wooden pallet' work placements, the agency pays a lower premium rate than the client employer, and accidents incur a lower experience-rated surcharge.

Client employers outsourced not just financial risk but also legal consequence. Key informants described how liability divestment was a key aspect of the TWA sector's value:

When they... price their work, they are adding all the potential liabilities into that price... There's a reason why there's a relationship [between TWAs and client employers] and it has very little to do in most cases with them... not wanting to 'do the HR [human resources] function', the way that temp agencies explain it. Most of it has to do with divesting themselves of liabilities. (Philip, workers' compensation regulator)

Although TWAs were liable for workers' compensation costs, including eventual surcharges imposed through experience rating, and despite the apparent low 'transfer of cost' uptake, their workers' compensation costs were low. Indeed, Ontario's TWA Safety Group members receive significant premium rebates. ${ }^{39}$ Once agencies secured contracts with client employers, they had various strategies for minimising workers' health and safety, and disability management, costs, as detailed in the following sections.

Due diligence and deniability 'safety nets'

Although transfer of cost could be contrary to business interests and challenged in tribunals, this option nonetheless provided a regular 'safety net' for this sector in the event of very high surcharges. To this end, and also in relation to liability under the OHSA, TWAs attempted to ensure a protected legal position with respect to allocating responsibility for work injury. Agencies described themselves as responsible for safety 'oversight' but not 'workforce management':

We have a responsibility from an oversight standpoint... but on an ongoing standpoint we can't manage the workforce, we don't own the building... the equipment. (Kate, CEO, multinational TWA) 
TWAs were aware that their workers faced risks that the agency could not always see or control. Therefore, safety became a matter of legal positioning. As described by a risk management specialist, in the absence of direct control over work conditions, agencies can only protect themselves from liability:

Lack of experience is always going to be a risk... and lack of knowledge of the site is always going to be a risk... That's almost impossible to manage... We try to take really good job orders, we try to give our workers a good outline of what the job is supposed to be on the site, we do ask our customers to give us site-specific... training when they get there, even if it's just a quick walk around and show them the hazards... We ask all of our clients to do that and they... sign off that they're going to do it. I don't know if they all do it, but... it's certainly asked to be done. And again... when you ask people to do things, you're asking them to do it in writing... you're hoping they will do it, but you know if they don't do it you're protecting yourself. Because if someone agreed to do something right and they don't do it and something happens, more of the liability goes on them. (Kendrick, risk management specialist, multinational TWA)

The acknowledged lack of control over the work site worked in the agencies' favour because it enabled 'deniability'. If TWAs do not control the work site, then they cannot be fully responsible for supervisory conduct and related workplace accidents:

There's a deniability the temp agency has in terms of what the problems are... You know, the machine didn't have a guard on it. 'Well, we didn't know that that was a problem. We were unaware of that.' (Jacob, OSH legal expert)

In all, agencies protected themselves from accident liability by clarifying their limited responsibility in contracts. This due diligence procedure, together with a related denial about work site practices, supports a provisional 'safety net' that allows the possibility of transferring accident costs to the client employer. This option has limitations, but nonetheless was a relatively systematic option available to the TWA sector. Essentially, it provides a market advantage that is rarely available to regular employers, allowing agencies to take financial risks.

\section{Managing the workers to lower claim costs}

Another way that the TWAs avoided workers' compensation costs was by managing workers so that accidents were not always reported and injury recovery time was not always claimed. Lowwage agency workers were particularly malleable because they were generally in a position of both extreme employment and financial insecurity, and were therefore unlikely to risk their job placement by 'speaking up' about working conditions or minor injuries. Despite this scenario, TWA staff expected workers to be an information conduit about the work site and health problems. They regularly described how temporary workers were instructed to inform them of safety hazards at their placement work site. However, as Lester, the owner of a small TWA explained, the viability of workers as an information conduit was unknown:

TWA: We can't be there $24 / 7 \ldots$ So we have to rely on our workers that are on the job site and they're instructed: 'If you see something... that's unsafe, then you ask your supervisor... to rectify the problem'... Or... ultimately... if nothing is done about it then... 'You're not obligated to do the job. You know... you can stop working on it. But you should kind of clarify it through your supervisor, you know, kind of work with them.' Interviewer: So, do you have workers coming back to you sometimes... ? TWA: Hmm, not very often... I am hoping that they will... bring it up. 
While some agency staff might 'hope' that a worker will speak up, the worker can be regarded as a 'tattletale' who disrupts the TWA's relationship with the client employer, as outlined by Joanne, a recruiter in a small TWA:

TWA: They usually call in and they will be like, 'You know what, I was training, I was put on this machine last night and I don't know how to use it...' [And we ask the client employer], 'Do they want to put him back on it?' Then they have to train him. Otherwise then he is going to go as a general labourer again... At that point the client may say, 'Well don't send him back then... we don't want him back because he is tattletaling on us.' Interviewer: So, then you have to send someone else?

TWA: Yeah.

Agencies had little power to change work site conditions, except by walking away from contracts. This could be a difficult choice in the competitive TWA industry. TWAs did describe avoiding badly organised or dangerous employer sites as 'not worth it'. However, once invested with a client employer, some would do little more than 'ask nicely' for changes:

On a construction site... they were working... at three or four stories high and there was a big opening, and... it wasn't railed off or guarded... so somebody could easily slip and fall over... So we asked them nicely on two or three occasions to do something about it and... one of our guys reported that nothing was done. So we said, 'Okay, you're off the job.'... You know... until they get it done we won't send you out there. (Lester, owner, small TWA)

Agency workers described quickly learning that if they report a problem at the work site, they will likely lose their job placement. This was not always an option they could afford:

We have to carry the heavy boxes... Eventually our agency said... 'Next time... let us know... because you're paid only for lighter things.' But in that situation you don't want to offend the... agency and also the employer. (Renshu, temporary worker)

Some workers went so far as to cover up each other's injuries, rather than 'rat out' a worker as less than fully employable:

I had a girl sprain an ankle... We had about an hour to go before [end time]. She says 'Look it... don't say anything, I've got an hour and then I am going to be going home'... [But then] the other one ratted [her] out. (Jackie, temporary worker)

Essentially, agency workers are disinclined to complain about hazards or injuries because this can mean losing the job placement. In turn, hazards are not reported, injuries are not documented, and agency workers are at further risk.

Agencies also avoided workers' compensation costs by actively discouraging and contesting workers' injury reports. Discouraging injury reports fell outside of 'playing by the rules'. Although agencies were required by the WSIB to report and manage any injury, regardless of severity, one agency described a deliberate strategy - including the requirement to fill out a long accident report - of suppressing any complaints that were not 'a serious accident':

They have to come in and fill in the 15-page accident report even if they don't see a doctor, because we need to understand what happened. Why did it happen, was it preventable? Because we see a lot of people take advantage of the system... [They say to themselves] 'If I 
get hurt at work... they're still going to pay me.' So... sometimes I have had people... come in and they fill in all of this paperwork and they're like, 'Oh my goodness... I wouldn't want to... if there wasn't a serious accident like I would just leave right now' and type of thing. (Kerry, recruiter, multinational TWA)

Some agencies also systematically fought any claim submitted to workers' compensation:

There were others who... would fight us on every claim. So... they were signing up saying, you know, 'We'll assume all of the responsibility to the claim', and then on the flipside every claim that came in they denied and questioned and fought. (Philip, workers' compensation regulator)

A key TWA strategy for fighting claim legitimacy appeared to be the argument that workers presented themselves to the agency with an undisclosed previous injury. In several cases, agency staff characterised workers as lying about pre-existing injuries and treating their injury claims as unworthy of serious consideration:

We come across it a lot... They are not upfront and letting us know that they have preexisting back injuries. They can do whatever job we're offering to them, lifting up to 50 pounds, yes, no problem. Get in there and... they hurt themselves... Some workers... feel they have no choice... They're... incentivised to lie because they get employment... Or they see it as a foot in the door because they really want to drive a forklift. 'We have no forklift truck driving right now... but we have lifting jobs right now... and that changes... from day to day.' (Vaughn, owner, mid-sized TWA)

Agencies that could not avoid an injury claim through the strategies detailed above could still minimise claim costs by reducing the 'lost time' due to the injury. Ontario employers are required to provide modified duties to a worker until they are able to resume essential duties of the pre-injury job, which for TWAs is essentially limited to placing the worker back on the roster. ${ }^{24}$ However, a common moral posture among TWAs was a reluctance to take up their formal obligation to provide modified duties:

You know... the tricky stuff in our business too is that... if the person is only out on the job, it's a one- or two-day assignment and they hurt themselves, they're off. And you've got to try and explain to the WSIB, 'Well... the assignment was only for two days... So they're missing one day's pay that they would have got.' So, now you're going to pay them for the next three months because they're off. (Lester, owner, small TWA)

When a successfully submitted claim required a TWA to provide modified work to a temporary worker, the agencies were necessarily ill-equipped because they are never the actual work site for the worker. Not surprisingly, some were reluctant to welcome unskilled workers into their agency office:

On more than one occasion we've had to bring people in our office... general labourers, pickers, packers who have no office skills... We would have them do filing... call applicants just to find out if they are still available, that sort of thing. But it's been quite a challenge and my boss is always objecting to it because he is saying, 'These people have no skills, how can I bring them in my office?' So, it's been a constant battle with WSIB for that... No one wants to deal with injured workers and [client employers]... they will tell you... right out that... 'I don't have modified [work]'. (Susan, recruiter, small TWA) 
Some agencies reduced premium costs by requiring workers to 'sign off' that they will not miss any work time following an accident, even before the extent of the injury is known. Lost-time costs were also reduced by promising employment to workers even when doctors advised rest, knowing that workers could not afford to decline the offer. As observed by Kendrick, an agency risk manager, the most vulnerable workers cannot afford to wait for a workers' compensation cheque:

TWA: Immediately we'll offer... them modified duties... We'll have them sign off that they understand there is modified duties available starting the next day at $8 \mathrm{am}$.

Interviewer: Okay, but you don't know what their injury is yet?

TWA: We'll have a basic idea... We will offer them based on standard restrictions and if we need to change it, we'll change it... Even if their medical says that [they] should have time off, we will still offer them modified duties. They have the right to refuse at that point but a lot of workers can't afford it. They can't afford to wait for the four weeks before the Board sends them their first cheque.

Unfortunately, an effect of aggressive early-return-to-work approaches can be that workers' injuries are exacerbated. However, workers' reluctance to speak up, together with their frequent movement between jobs and agencies, reduces the likelihood of the injury cost being traced to the agency promoting these practices.

Shutting down

A final accident cost management strategy was to shut down and re-open the agency. TWAs (especially small-sized) are particularly well set up for this strategy because they can operate with few overheads. As wryly remarked by a workers' compensation regulator, the only capital equipment needed to run an agency is a telephone:

They are opening and closing all the time, going bankrupt... I mean, you can run a temporary agency with a BlackBerry, right?... But you're sucking that accident cost with you. (Arthur, workers' compensation regulator)

Under the WSIA, company directors are accountable for monies owed to the WSIB. However, they can escape responsibility for these debts if the business shuts down and the directors have no identifiable assets. Typically, it is the death of a worker that prompts such closures:

[TWA name]... went out of business because of the fatality. And then I went back, they weren't at the location. So then I got hold of someone in the compensation board and... they... said, 'Oh... they're not [former name] any more, they're now [new name]. They just went with the initials and they changed the director of the company and they moved down the hall.' (Joseph, OSH inspector)

When the TWA shuts down without assets, no one is held accountable for worker protection. Those responsible escape both compensation costs and liability for the unpaid wages of all employees.

\section{Discussion}

Experience rating is normally discussed in terms of its aims and effectiveness in relation to workplace health and safety, but rarely in terms of encouraging the development of a sector to which workers' compensation financial risk can be outsourced. In 1986, Ison ${ }^{41}$ predicted that punitive financial aspects of experience rating would prompt employers to contract-out 
hazardous work. While Quinlan et $a l .^{42}$ have addressed this in relation to subcontracting, it has rarely been examined in relation to the TWA sector. In this paper, we argue that the transformation of health and safety into a financial incentive, via the experience rating of workers' compensation costs, has made health and safety a financial transaction to be 'gamed' by employers. Employers can avoid experience-rating costs without actually addressing workplace health and safety, particularly as applied in Ontario, where the TWA pays the workers' compensation premium and any rated surcharges.

A critical element of the relationship between experience rating and the TWA sector is the financial advantage it poses for agencies, all within the boundaries of the law. Further, the low workers' compensation premium rate group for TWAs relative to that of employers with recognisably dangerous work creates a market for the outsourcing of dangerous work. Ontario TWAs positioned themselves legally to avoid some blame for injuries and, in some cases, could transfer the cost of experience rating to the client employer. This option appeared to be exercised only rarely, but as a regularly available safety net it allows TWAs to take business risks. In the case of low-wage workers, there was under-reporting of injuries and hazards related to economic insecurity, but agencies did little to acknowledge or address workers' disinclination to speak up.

TWAs also managed the experience-rating costs of 'lost time' through aggressive return-to-work strategies. Although this could prompt more severe injuries and increased experience-rating costs, the short-term nature of temporary work can disassociate an agency's practices from later financial consequences.

Experience-rating incentives for return to work are especially problematic when applied to TWAs because the agency is never the work site of the injured worker. The TWA 'product of convenience' is incongruent to placing injured workers with client employers. As the agency's return-to-work obligation is limited to placing the worker on its employee roster, in the event of non-placement, this leaves it open to the TWA to explain that it is the client employer who does not want the worker's services. ${ }^{24}$

Structural challenges and the OSH accountability gap

Research is needed that recognises the institutional place of TWAs in broader employment systems. ${ }^{9}$ Indeed, dialogue on TWAs and worker vulnerability has depended on a problem frame focused on 'bad apples' in the industry, leading to only incremental steps toward agency employment regulation and a neglect of the broader structural picture. ${ }^{43}$ However, our argument is not about individual agency negligence, but rather the structural conditions that relieve both TWAs and client employers of full employer responsibilities and create increased risk to agency workers.

In the context of the triangular employment relationship, defining who the 'employer' is is complex. In Ontario, the OHSA holds both the TWA and the client employer responsible, and potentially applies fines to both. ${ }^{24}$ But, under the WSIA, only the TWA is considered the employer. In theory, both the agency and the client employer clearly understand their occupational health responsibilities. However, shared responsibilities create ambiguities, ${ }^{43}$ and TWAs' willingness to hold client employers to account is strongly tempered by the fear of losing commercial arrangements with the client employer. ${ }^{16}$

The complications of safeguarding agency workers' health will only worsen with the increasing use of the 'consolidated vendor' approach. With this model, the client employer uses a single agency as its primary supplier of temporary workers and this agency, in turn, hires workers 
from various other agencies. ${ }^{14,44}$ In this scenario, workers are hired at an extended distance from the principal employer - which makes the complex triangular employment relationship look relatively simple.

\section{Applying experience rating to the work site employer}

The issue arises as to what would happen if experience-rated workers' compensation premiums were applied to the employer controlling the work site, ie the client employer. It could result in a reduction of contracts to the TWA sector, primarily those contracts that are 'gamed' for OSH savings. It could also result in increased protection for agency workers, because the client employer has a structural interest in experience-rating costs related to them. Client employers would be obliged to provide modified work to an injured agency worker, which could motivate them to not distinguish their responsibilities to agency and other workers on their work site. It could also induce client employers to address particular health and safety risks of temporary workers, such as newness on the job. ${ }^{19}$

The designation of the TWA as employer, rather than an intermediary, is not inevitable. Intense lobbying of governments was undertaken by TWAs in the USA ${ }^{45-46}$ and Great Britain ${ }^{47}$ in the late 1960s and 1970s to secure this legal role. Further lobbying by those opposed to this arrangement could change this position. A central purpose of the present legal arrangement is that it allows client employers to use labour while avoiding many social, legal and contractual obligations. ${ }^{45,48}$ As such, the employer role secures the place of TWAs in the market. However, in Canada, the status of TWAs as 'employers' differs depending on the legislative framework. In 1997, a Supreme Court of Canada judgement involving a TWA ${ }^{49}$ noted that legislation must be adjusted in non-traditional employment relationships to meet the specific objectives of the legislation. Similarly, the Ontario Labour Relations Board acknowledged the client employer as employer for the purposes of the Labour Relations Act, despite concluding that the TWA was the employer for the purpose of the Employment Standards Act. ${ }^{50}$ In relation to occupational health, TWAs hold varying statuses under Ontario legislation. ${ }^{24}$ Under the WSIA, the TWA is currently regarded as the sole employer. However, the OHSA considers both the client employer and the TWA as employer. This range of interpretations of Canadian legislation confirms that complex employment relationships require a practical approach to the allocation of responsibility. It is plausible that, in the context of the triangular TWA employment structure, premium-setting and experience-rating rules could be adapted to provide incentives to client employers to prevent risks and injuries to all workers at a work site.

\section{Temporary agency sector politics}

This exploration of the relationship between experience rating and the TWA sector in Ontario reveals a structural problem requiring policy reform. However, maintaining the legal status quo is in the interests of both the TWA sector and the client employers. The Association of Canadian Search, Employment and Staffing Services - an industry organisation that describes itself as 'the voice of the staffing services and recruitment industry' - has as a 'primary objective' to 'actively represent the industry and... membership before governments by providing input on employment legislation and regulations at the national and provincial levels'. ${ }^{51}$ However, this association has not spoken against the 'sole employer' position of its members vis-à-vis the WSIA, despite agencies' minimal ability to manage injury risk and return to work.

A key party lacking a direct voice in policy reform is that of workers in low-skill jobs, who seek employment through agencies and are dispersed and disconnected. Effective public policy requires representation from all parties, including workers, and their ability to exercise 
collective agency is essential for discussion about social investments and protections that could address the problems raised by precarious work. ${ }^{52}$ However, in Canada and elsewhere, those working through TWAs are least likely to be unionised ${ }^{48,53-54}$ and TWAs may actually exert a negative pressure on union growth. ${ }^{43}$ Essentially, TWA workers are left struggling for protection equal to that of regular workers. ${ }^{26,55}$

\section{Conclusions}

In this paper we have argued that, by transforming workplace safety into a financial incentive issue and linking workers' compensation and related costs to individual businesses, experience rating has encouraged the establishment of the TWA sector, whose market share is enhanced by its ability to absorb cost and risk from client employers. Further, we argue that experience-rating rules as applied to this sector in Ontario facilitate gaming largely within the rules. We have detailed key dimensions of this relationship between experience rating and the TWA sector. Experience-rating arrangements situate the agency as the employer that pays workers' compensation premiums and related surcharges, thus creating a market to which employers can outsource risky jobs. What is particularly troubling about hazardous work falling to this sector is that agencies are in a poor position to assure the protection of their workers. However, TWAs absorb workers' compensation costs for the client employer. Favourable premium rate groups allow agencies to price contracts to absorb injury costs. As well, TWAs have the flexibility to avoid work accident costs through legal positioning; the 'transfer of cost' safety net; influencing accident reporting and return-to-work practices among low-wage, insecurely employed workers; and by shutting down the business.

We propose that experience-rating rules distort agency and client employer responsibility for work and health, and have fostered Ontario's TWA sector. If experience-rating financial incentives were applied to the party actually controlling the conditions of work, that is, the client employer, agency workers could receive protection more comparable to that of regular workers. This would make experience rating a less tradeable commodity, and worker safety and return to work a more significant priority for the work site employer.

\section{Acknowledgments}

This study was funded by the WSIB Research Advisory Council. We are grateful to the members of the study's Advisory Committee for their advice and input and thank the study participants for sharing their insights and experience with us. Finally, we appreciate the reviewers' feedback, which strengthened the paper.

\section{References}

1. Hopkins A. The effect of workers' compensation premium incentives on health and safety. Journal of Occupational Health and Safety - Australia and New Zealand 1994; 10 (2): 129-136.

2. Clayton A. The prevention of occupational injuries and illness: the role of economic incentives. Canberra: Australian National University, National Research Centre for OHS Regulation, 2002. https://digitalcollections.anu.edu.au/bitstream/1885/41128/ 3/working_paper_5.pdf. Viewed 16 May 2012.

3. Storey R. 'Their only power was moral': the Injured Workers' Movement in Toronto, 1970-1985. Social History 2008; 41 (81): 99-131.

4. Harcourt M, Lam H and Harcourt S. The impact of workers' compensation experience rating on discriminatory hiring practices. Journal of Economic Issues 2007; 16 (3): 681-699. 
5. MacEachen E, Kosny A, Ferrier S and Chambers L. The 'toxic dose' of system problems: why some injured workers don't return to work as expected. Journal of Occupational Rehabilitation 2010; 20 (3): 349-366.

6. Hyatt D E and Kralj B. The impact of workers' compensation experience rating on employer appeals activity. Industrial Relations 1995; 34 (1): 95-106.

7. Morneau Sobeco. Recommendations for experience rating. Toronto: WSIB, 2008. www.wsib.on.ca/files/Content/Downloadable\%20FileExperienceRatingReport/ MorneauSobecoReport.pdf. Viewed 08 May 2012.

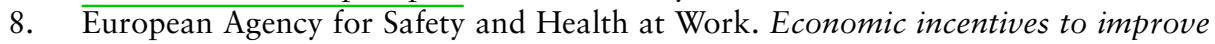
occupational safety and health: a review from the European perspective. Luxembourg: Publications Office of the European Union, 2010. http:/osha.europa.eu/en/ publications/reports/economic_incentives_TE3109255ENC. Viewed 08 May 2012.

9. Coe N M, Jones $\mathrm{K}$ and Ward $\mathrm{K}$. The business of temporary staffing: a developing research agenda. Geography Compass 2010; 4 (8): 1055-1068.

10. Luo T, Mann A and Holden R. The expanding role of temporary help services from 1990 to 2008. Monthly Labor Review 2010; August: 3-16.

11. Atkinson J. Manpower strategies for flexible organizations. Personnel Management 1984; August: 28-31.

12. Connell J and Burgess J. In search of flexibility: implications for temporary agency workers and human resource management. Australian Bulletin of Labour 2002; 28 (4): 272-283.

13. Ward K, Grimshaw D, Rubery J, Beynon H. Dilemmas in the management of temporary work agency staff. Human Resource Management Journal 2001; 11 (4): 3-21.

14. Hatton E. The temp economy: from Kelly girls to permatemps in postwar America. Philadelphia: Temple University Press, 2011.

15. Johnstone R and Quinlan M. The OHS regulatory challenges posed by agency workers: evidence from Australia. Employee Relations 2006; 28 (3): 273-289.

16. Underhill E. Should host employers have greater responsibility for temporary agency workers' employment rights? Asia Pacific Journal of Human Resources 2010; 48 (3): 338-355.

17. Neugart $\mathrm{M}$ and Storrie D. The emergence of temporary work agencies. Oxford Economic Papers 2006; 58 (1): 137-156.

18. Statistics Canada. Study: earnings of temporary versus permanent employees. 2003. www.statcan.gc.ca/daily-quotidien/050126/dq050126b-eng.htm. Viewed 08 May 2012.

19. Underhill E and Quinlan M. How precarious employment affects health and safety at work: the case of temporary agency workers. Relations industrielles/Industrial Relations 2011; 66 (3): 397-420.

20. Purcell J, Purcell K and Tailby S. Temporary work agencies: here today, gone tomorrow? British Journal of Industrial Relations 2004; 42 (4): 705-725.

21. Public Service Commission of Canada. Use of temporary help services in public service organizations. Ottawa: PSC, 2010. www.psc-cfp.gc.ca/adt-vrf/rprt/2010/th-at/th-ateng.pdf. Viewed 08 May 2012.

22. Workplace Safety and Insurance Act, 1997: section 43. www.e-laws.gov.on.ca/html/ statutes/english/elaws_statutes_97w16_e.htm. Viewed 16 May 2012.

23. European Union. Temporary Agency Work Directive. Press release. MEMO/08/646. Brussels, 22 October 2008. http://europa.eu/rapid/pressReleasesAction.do? reference= MEMO/08/646\&type=HTML Viewed 08 May 2012.

24. Lippel K, MacEachen E, Saunders R, Werhun N, Kosny A, Mansfield L, Carrasco C and Pugliese D. Legal protections governing occupational health and safety and workers' compensation of temporary employment agency workers in Canada: 
reflections on regulatory effectiveness. Policy and Practice in Health and Safety 2011; 9 (2): 69-90.

25. Law Commission of Canada. Is work working? Work laws that do a better job. Ottawa: LCC, 2004. http://publications.gc.ca/collections/Collection/JL2-24-2004E.pdf. Viewed 08 May 2012.

26. Kalleberg A L, Reskin B F and Hudson K. Bad jobs in America: standard and nonstandard employment relations and job quality in the United States. American Sociological Review 2000; 65 (2): 256-278.

27. Ontario Ministry of Labour. A consultation paper on work through temporary help agencies. Toronto: Ministry of Labour, 2008. www.ontla.on.ca/library/repository/mon/ 22000/282964.pdf. Viewed 08 May 2012.

28. Quinlan M. Regulatory responses to OHS problems posed by the increasing use of direct-hire temporary workers in Australia. Journal of Occupational Health and Safety Australia and New Zealand 2004; 20 (3): 241-254.

29. Benavides F G, Benach J, Muntaner C, Delclos G L, Catot N and Amable M. Associations between temporary employment and occupational injury: what are the mechanisms? Occupational and Environmental Medicine 2006; 63: 416-421.

30. European Foundation for the Improvement of Living and Working Conditions. Temporary agency work in the European Union. Dublin: EFILWC, 2007. www.eurofound.europa.eu/ewco/reports/TN0408TR01/TN0408TR01.pdf. Viewed 08 May 2012.

31. Hintikka N. Accidents at work during temporary agency work in Finland - Comparisons between certain major industries and other industries. Safety Science 2011; 49 (3): $473-483$.

32. Smith C K, Silverstein B A, Bonauto D K, Adams D and Fan Z J. Temporary workers in Washington State. American Journal of Industrial Medicine 2010; 53 (2): 135-145.

33. Park Y-S and Butler R. The safety costs of contingent work: evidence from Minnesota. Journal of Labor Research 2001; 22 (4): 831-849.

34. Clarke A E. Situational analysis: grounded theory after the postmodern turn. Thousand Oaks: Sage, 2005.

35. Richards L. Handling qualitative data: a practical guide. London: Sage, 2005.

36. Workplace Safety and Insurance Board. NEER (New Experimental Experience Rating Plan): operational policy manual. Toronto: WSIB, 2012. www.wsib.on.ca/en/community/ WSIB/OPMDetail?vgnextoid=9604fcea9bfc7210VgnVCM100000449c710aRCRD. Viewed 16 May 2012.

37. Occupational Health and Safety Act, 1990. www.e-laws.gov.on.ca/html/statutes/english/ elaws_statutes_90o01_e.htm. Viewed 16 May 2012.

38. Workplace Safety and Insurance Board. 2011 Premium rates. Toronto: Workplace Safety and Insurance Board, 2011. www.wsib.on.ca/en/community/WSIB/ ArticleDetail?vgnextoid=0bad811f0e9eb210VgnVCM100000469c710aRCRD. Viewed 08 May 2012.

39. Workplace Safety and Insurance Board. Safety groups yearly rebate. Toronto: WSIB, 2012.

40. Workplace Safety and Insurance Appeals Tribunal. Decision No. 111/91. CanLII 5253 Canadian Legal Information Institute, 1991; www.canlii.org/en/on/onwsiat/doc/1991/ 1991canlii5253/1991canlii5253.html. Viewed 08 May 2012.

41. Ison T G. The significance of experience rating. Osgoode Hall Law Journal 1986; 24 (4): 723-742.

42. Quinlan M, Mayhew C and Bohle P. The global expansion of precarious employment, work disorganization, and consequences for occupational health: placing the debate in a 
comparative historical context. International Journal of Health Sciences 2001; 31 (3): 507-536.

43. Bartkiw T J. Baby steps? Toward the regulation of temporary help agency employment in Canada. Comparative Labor Law \& Policy Journal 2009; 31 (1): 163-210.

44. Hoque K, Kirkpatrick I, Lonsdale C and De Ruyter A. Outsourcing the procurement of agency workers: the impact of vendor managed services in English social care. Work, Employment \& Society 2011; 25 (3): 522-539.

45. Gonos G. The contest over 'employer' status in the postwar United States: the case of temporary help firms. Law \& Society Review 1997; 31 (1): 81-109.

46. Peck J A and Theodore N. Temped out? Industry rhetoric, labor regulation and economic restructuring in the temporary staffing business. Economic and Industrial Democracy 2002; 23 (2): 143-175

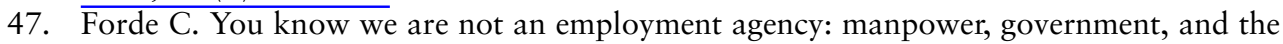
development of the temporary help industry in Britain. Enterprise \& Society 2008; 9 (2): 337-365.

48. $\overline{\text { Freeman }} \mathrm{H}$ and Gonos G. Regulating the employment sharks: reconceptualizing the legal status of the commercial temp agency. WorkingUSA: The Journal of Labor and Society 2005; 8 (3): 293-314.

49. Pointe-Claire (City) v. Quebec (Labour Court), [1997] 1 SCR 1015, Supreme Court (1996: November 6; 1997: April 24, 1997).

50. National Waste Services Inc., [2009] OLRB Rep. May/June 415, No. 0939-07-R, No. 0939-07-R (2009). http://kwlc.ca/fileadmin/pdf/National_Waste_Services_Inc.,_ \%5B2009\%5D_O.L.R.D\%5B1\%5D.pdf. Viewed 16 May 2012.

51. Association of Canadian Search, Employment and Staffing Services. Government relations. Toronto: ACSESS, 2012. www.acsess.org/GOVERNMENT/default.asp. Viewed 08 May 2012. (Login details required to access this publication.)

52. Kalleberg A L. Precarious work, insecure workers: employment relations in transition. American Sociological Review 2009; 74 (1): 1-22.

53. Fuller S and Vosko L. Temporary employment and social inequality in Canada: exploring intersections of gender, race and immigration status. Social Indicators Research 2008; 88 (1): 31-50.

54. Gottfried H. In the margins: flexibility as a mode of regulation in the temporary help service industry. Work, Employment and Society 1992; 6 (3): 443-460.

55. Workers' Action Centre and Parkdale Community Legal Services. Submission to the Ministry of Labour consultation on work through temporary help agencies. Toronto: Workers' Action Centre, 2008. www.workersactioncentre.org/!docs/ sb_TempConsultMay\%202008_eng.pdf. Viewed 16 May 2012. 